\title{
Leadership as a Way of Being: A Way Forward for a News Industry in Chaotic Transition
}

\author{
Dr. Keith Herndon \\ Dr. Richard McCline
}

\begin{abstract}
Hesselbein developed the concept: "leadership is a matter of how to be and not how to do." Joseph later provided instructional content based on the concept and helped operationalize it for consumption by practicing leaders. This paper leverages their work in illustrating how leadership-as-a-way-of-being (LWB) can be a teaching model for emerging millennial leaders in a dynamic news media undergoing a chaotic transition. It provides a way to rethink newsroom organizational structures that no longer accommodate the needs of this generation. We focus on the "being" element of leadership as it speaks directly to a new introspective view of leadership that values transparency and is necessary for innovation over mere efficiency.
\end{abstract}

\section{Introduction}

"The most enduring value of a news organization is honesty. You need to have the reporters and professionals understand that the ownership and the leadership value integrity above all else." - Nancy Maynard

The legendary leader Frances Hesselbein (2010) is credited with originating the concept of "leadership is a matter of how to be and not how to do." Joseph (2012) provided instructional content to operationalize the concept for practicing leaders. This paper leverages their work in illustrating how leadership-as-a-way-of-being (LWB) can be a teaching model for training emerging millennial leaders in a news media undergoing a chaotic transition. This is a powerful way to rethink organizational structures that no longer meet the needs of a new generation of journalists. (The introductory quote is from Best Practices: The Art of Leadership in News Organizations by Shelby Coffey III. Nancy Maynard had worked as a reporter for The New York Times and was later publisher and co-owner of The Oakland Tribune in California.)

Our discussion offers a practitioner's perspective as to how an entrepreneurial orientation, a commitment to ethical principles, and a streamlined organizational structure can become the necessary strategic foundation for leaders seeking new solutions for the news industry. We comment on how the LWB model can be inherently innovative for a traditionbound industry and why it is especially appropriate for the emergence of millennials as news media leaders. We focus on "being" as the driving element of leadership, an attribute that reflects an emphasis on introspective leadership in which innovation represents a higher value proposition than mere efficiency.

The elements that define an LBW model - ethical values, transparency, entrepreneurial vision and flat organizational structures - all should resonate within a news industry gripped by the chaos of business model transition and political polarization. Before explaining how the 
LBW model can be applied in such an industry setting, it is important to provide proper context. The following section describes the news industry's circumstances.

\section{A News Media in Transition}

Leading a news organization in an era of instant distribution, social media commentary, and economic uncertainty is fraught with challenges. These challenges became especially pronounced in a politically polarized climate when the sitting President castigated the press "as an enemy of the American people" and adapted the phrase "fake news" to describe any reporting he found unfavorable (Grynbaum, 2017; Griffin, 2017).

Covey (1990), writing with no particular industry in mind, noted that every transaction within a marketplace can be a moral challenge to see that both parties come out fairly. Within the news media, these transactions involve sources, advertisers and audience all observing and interacting with the activity without fully appreciating the decades of tradition that aims to project balanced and unbiased reporting (Fink, 1996).

Neil Shapiro, former president of NBC News, described the journalistic context this way: "There is something honorable about finding the truth and doing the best you can to eliminate your biases, and say that wherever the story is going to take me is where I am going to go" (Coffey, 2002). The news industry has long cherished its role in American democracy and used its Constitutional protection found in the First Amendment to attract journalists interested in the work as a noble calling. Fink (1996) maintained the news business "must have higher ideals than making money, responsibilities beyond keeping shareholders happy." He acknowledged, however, that producing news is a business venture, which required profits to remain viable. (p. $\mathrm{xxi})$.

The challenges Fink discussed - declining revenue, shrinking audience, industry consolidation - have all accelerated in the post-Internet era resulting in a news industry in transition and chaos. For example, newspaper industry employment has collapsed, falling by more than 60 percent since 1990. There are now more people working at online publications than at newspapers (Lichterman, 2016). The transition is rippling throughout all forms of the news media, forcing smaller companies to align with larger ones, others to divest and many others to significantly restructure. Billions of dollars of new risk capital are flowing into a market where old capital is looking to escape. Mergers and acquisition deals in the media sector reached $\$ 180$ billion in 2015, "exceeding the combined value of transactions completed over the preceding four years" (Mann, Venturini \& Malhotra, 2016).

Against this backdrop, Nelson and Lewis, wrote "the schools that train journalists are likewise trying to sort through what it means to prepare journalists for this changing field," adding that "journalism schools are in a crisis of identity" (2015, p. 394, 404). Pavlik asserted "educators need to transform media education at every level, from the nature of and work of a media professional, to the content, organizational, and financial structure of the media and their relationships with the public."(2013, p. 215). As journalism education restructures to teach its students about the new business realities, Förster and Rohn emphasized "that students not only learn how economic and financial aspects affect media organizations but are also able to fulfill 
social and societal responsibilities within an ethical framework" (2015, p. 369).

Given the significant issues facing contemporary news leaders, we believe that it is important to explicitly define a leadership model that provides such an ethical framework. In the following sections, we present the LWB model and explain how its principles are best suited for developing leaders capable of navigating the political, technological, and financial challenges inherent in today's news media.

\section{Defining the LWB Model}

The LWB model is, in our view, a contemporary philosophy that describes the leader who lives by a set of core values and allows others to see authenticity through transparency of actions. Our insistence that the leader must be guided, first, by a well-developed moral compass is an important emphasis over typical other definitions of leadership that speak primarily to the leader's ability to develop a shared vision and possess a charismatic personality. An inspirational and charismatic persona falls short unless it is infused with an ethical orientation attuned to the nuances inherent in a leader's individual approach.

The LWB model of leadership focuses on the importance of the leader's internal moral compass. We argue that a positive moral compass has invaluable utility in helping leaders cope with the moral and ethical dilemmas that confound decision making in organizations of all sizes and sectors (Greenleaf, 1977; Joseph, 2012; Poon, 2006). This requires introspection from those subscribing to the LWB model which emphasizes the importance of leaders knowing themselves and the values they are committed to before seeking to wield influence over others (De Pree, 1997; Joseph, 2012).

As LWB leaders engage in meaningful reflection, they must extract themselves from routines of the present to envision a future in which things are as they could be, not as they are. As we advocate for a specific type of strategic leader, we must consider the type of organizational structure in which such a leader would fit in our behavior model. The predominate organizational reality in today's business culture continues to reflect the vertical, or pyramidal, design made famous by industrial leaders such as John D. Rockefeller and his peers in the late nineteenth and early twentieth centuries. (Management theorists will quickly want to recognize the contribution of individuals like Max Weber, Henri Fajol and Frederick Taylor. However, our reference to John D. Rockefeller's highly centralized management system provides a more universal reference.) Multilayered, hierarchical organizations concentrate decision making power within a formal chain of command. In this design everyone in an organization is a subordinate to someone. Even the authority of the Chief Executive Officer is subject to oversight from a board of directors. The organizing principles of the top-down strategic organizational design advocated, and generally require discipline, unity of command and subordination to the thoughts and directions from those who are a step above on the organizational ladder (Porter \& Siegel, 2006).

Despite the stubborn entrenchment of hierarchical organizational structures, we suggest that LWB leaders are most likely to be effective within an organizational design structure that disperses power among its members up, down and around formal chains of command. For this 
reason, we believe flat organizational structures will increase in prominence. We are not implying that no layers of responsibility and accountability are appropriate. Leaders must have followers in which to delegate and carry out the work that will propel an organization forward. Our primary purpose is to raise an increased awareness that in today's hyper-competitive marketplace, response time is critical. We believe workers are increasingly embracing the same expectations of customers, which is immediate feedback and response to their questions, suggestions and concerns. Organizations that can develop new technologies faster and adapt to changes in the market more readily will survive. Flat organizations are structured to make decisions more quickly. This observation is not especially novel. Our contribution is to link this organizational design approach with a specifically appropriate approach to leadership, best captured by the LWB model. With fewer levels of management, workers are empowered to make decisions. The LWB leader, within a flattened organizational chart, is positioned to be an active listener, freely sharing information and seeking open and transparent feedback from all facets of the organization. (Graham, 1991; Greenleaf, 1977; Joseph, 2012; Russell, 2001).

Success for LWB leaders is not about "I" or "me" but about "we" and "us." Leaders operating in this model are willing to listen and collaborate such that their role is not about what is known but more about one's ability to be fully present. LWB leaders live their values and make their actions consistent with their values. They work at being who they say they are by applying the values and standards of conduct they believe in. They are committed to doing the right thing because of who they are. They do not always succeed, but when they don't, they work at learning from those failures. LWB leaders are able to use an internal sense of their moral selves to facilitate the creation of trust between themselves and others in their organization. Trust reflects a sense of honest humility that allows close interpersonal relationships to prosper (De Pree, 2003; Senge, 2006).

Finally, an entrepreneurial orientation in the behavior patterns of a LWB leader is perhaps the most unique and essential characteristic of our values-based leadership model. (McCline, Bhat \& Baj, 2000). The literature on this aspect of the model tells us that entrepreneurial leaders see opportunities where others only see problems (Gaglio \& Katz, 2001; Timmons, 1989; Timmons \& Spinelli, 2009). The LWB model embraces such entrepreneurial behavior because it reinforces inquiry and reflection about who they are and what they want their organizations to become.

Leadership is about inspiring followers to achieve common goals, which applies to team leaders, division heads, owners and chief executives. Leaders at all ranks are expected to take their groups, their companies, or their organizations to places they would not likely go if not for the presence of an inspirational leader. Thus, LWB leaders, by their very nature, must be risktakers unafraid of taking on calculated risk. Combining an appetite for risk with creative thinking can result in innovative action that is the hallmark of the behavior pattern recognized in successful entrepreneurial leaders (Timmons \& Spinelli, 2009; McCline et al, 2000).

\section{Connecting the LWB model to News Leader Challenges}

The LWB model directly addresses journalistic challenges of fairness and ethics through a usable framework for guiding a leader's actions. In our view, this leadership model is an inside 
out approach, a search inside one's self for clarity on universal principles that can guide behavior toward actions that increase the welfare of others while moving a news organization toward its goals of fair reporting, financial success and business sustainability.

Nevertheless, the LWB model reflects a strategically different perspective on leadership and followership as it has been practiced historically in most news organizations. In the model we recommend, the leader serves - as well as leads - the people around him/her. The leader 'commands' rarely - mostly in those circumstances requiring immediate action from those who follow. Adopting this approach will require structural changes in newsrooms where power is distributed in a classically hierarchical way. The kind of restructuring - in thinking and in organizational pattern - will require a commitment by all to fairness in process (Breeden, 2013; Bunderson, 2001).

To a significant degree, the LWB leader works from the premise that the more power is shared within an organization, the more powerful the organization becomes. Goals and objectives are more likely achieved because its members actively commit to and are empowered to achieve them. Each member of the organization is an important piece of the puzzle that moves the organization toward success. The importance of the individual contributor is insisted upon by the leader and accepted and expected by the followers. We are not advocating inverting the pyramid which would still imply a top and bottom. The flat table concept envisions more of a circle of organizational equals. We believe flat table organizational designs are much more likely to facilitate the industry's efforts to renew itself.

The flat table design recognizes that organizations have both a social and business focus. Effective LWB leaders use the flat table design principle to give each follower a "seat at the table" and a flat plane at which their thoughts, suggestions and insights are not sent upward but across to the LWB leader. The structure we are advocating for the LWB-led news organization is one that is much more likely to ensure that all participants can be seen and all voices heard. A sense of safety emerges from engaging with leaders in this way and is another preferred organizational outcome. Our point is not to suggest that everyone is equal in terms of skills and overall contributions to success. However, we are suggesting that leaders who provide equal levels of respect, communication and access to opportunities (formal and informal) tend to foster creative thinking, which lifts their followers to the limits of their abilities and motivations.

Accomplishing this requires an LBW leader to think in terms of "fair process attributes," which we identify as Interpersonal Justice, Informational Justice, and Reciprocal Communication. These attributes have been the subject of much research and discussion (Folger \& Bies, 1989; Dantley \& Tillman, 2006; Kernan \& Hanges, 2002; Larson \& Murtadha, 2002) and our goal is not to redefine them here. Instead, we offer a brief common sense understanding of each of the attributes, demonstrating the relevance of each in our overall examination of how incorporating them enhances the approach of LWB leaders.

Interpersonal Justice: This is about truth telling: making it known to all that each person in the organization matters; giving respect to each regardless of title and position on the organization chart: and making sure that input is sought from all employees. An expected 
outcome of this flat table model is heightened self-esteem and self-actualization for each.

The LWB model encourages the leader, at any level of responsibility, to be aware of her/his practical and emotional strengths and limitations. And it encourages other members of the organization to express their strengths in a complementary fashion. Openly shared information facilitates innovation because it deepens a more complete understanding of what is happening within sub-groups and across the whole organization. Thus, interpersonal justice, as defined here enhances the sense of ownership and an added commitment to work across the board. At the personal level, another expected outcome of the LWB model in practice is that all employees will experience a greater, more informed sense of positive self-worth because the contributions of each are appreciated (Mayer, Nishii, et. al, 2007; Colquitt, 2001).

Informational Justice: This form of justice is evidenced by the wide sharing of facts, important thoughts, key assumptions that are communicated up, down and across. All organizational participants have access to information with as much transparency as possible; secret agendas are not allowed to exist. Explanations and transparency in decision making contributes to a sense of fairness in how decisions are made. The goal is not only sharing information but also minimizing misinformation. For example, informational Justice focuses on explanations organizations provide to staff about why certain procedures were followed or why resources were distributed in certain ways (Greenberg, 1990). Research suggests that cogent justifications for decisions strongly influence perceptions of fair treatment in organizations (Folger \& Bies, 1989). Also explanations characterized as reasonable, timely and specific influence these perceptions (Brocker, Konovsky, et. al). An expected outcome of increases in informational justice is a strengthened sense that the leaders are learning from one another and from other employees as information is pooled rather than collected and stored in departmental and/or hierarchical silos (Mayer, Nishii, et. al, 2007, Colquitt, 2001).

Reciprocal Communication: This element of the process is about establishing two-way conversations as an organizational norm. The LWB model encourages the practice of reciprocity in the circular relationship between leaders and followers. The focus is not on polite small talk, but rather on mutual sharing of ideas and perceptions in settings where titles and positions do not affect their validity and relevancy. Leaders in our organizational model are not anointed to speak the only "truths" that influence perception and the consequent actions. Instead, organizational members are encouraged to express themselves because their thoughts contribute to a better understanding of the realities that influence organizational action.

We admit that there is some room for selected expertise to add to the substance of discourse. That is consistent with other studies of how influence emerges within groups. This organizational attribute gives all members of the organization chances to contribute meaningfully and to celebrate the good news that permeates the organization with almost the same speed as unfortunate news (Bell \& Kozlowski, 2002). Reciprocal communication embeds respect for whoever makes a thoughtful and added contribution by focusing on hearing and being heard. Conversely, telling someone unbidden how to do something may not be received as respectful communication. 
What's important are body language, the tone of delivery, and an individualized message. When leaders and followers have two-way conversations, respect flows in both directions. This practice is sometimes captured as "leading from any chair" to convey the thought that it makes no difference where leaders sit when it comes to leading their groups.

An expected outcome of reciprocal communication is the phenomenon of voluntary followership. This implies that leadership is not achieved by mandate but through vision sharing. This sharing tends to engage and inspire all organizational members toward a common goal defined by all as success. Each party in the conversation is present. The focus in each case is on the person speaking. The team looks for common ground, a process that may take time away from the conversation to allow each participant to digest the message and define meaning that moves the group forward. The two-way flow of conversation helps the followers and leader(s) reach a consensus of what is both meaningful and valuable and, therefore, justifies the expenditure of resources to be used in pursuit of shared goals. (Hambley, O'Neill \& Kline, 2007).

The nature of this process in inherently empowering and speaks to an emerging generation of employees who seek ways to make their work meaningful and their contributions genuinely impactful within an organization.

\section{Preparing Newsrooms for the Generational Shift}

The significant generational shift underway in the U.S. workforce provides an ideal setting for implementing the LWB model in news organizations. A report compiled by the Pew Research Center noted that "generations are analytical constructs, and developing a popular and expert consensus on what marks the boundaries between one generation and the next takes time" (Fry, 2016).

For example, labor for nearly three decades was dominated by maturing baby boomers. This highly influential cohort first rebelled against authority, but, as they matured, they tended to accept, respect and comply with formal structure and established lines of authority. The hierarchical design survived largely unchanged since members of generation X did little to upset the existing structure. The arrival of millennials, however, is a different matter given that their emergence is timed against a vast baby boomer retirement.

The Pew Research Center defines millennials as the generation aged 18-34 in 2015. Based on that age bracket, data from the U.S. Census Bureau indicates there are more than 75 million millennials, which means the group has "surpassed Baby Boomers as the nation's largest living generation" (Fry, 2016). Earlier, millennials had established themselves as the largest sector of the U.S. workforce (Fry, 2015).

Rikleen (2014) observed millennials are "bringing into the workplace extraordinary energy and significant resolve to shape the type of workplace they are seeking." The millennial workforce wants a place at the decision-making table and it harbors minimal respect for a hierarchical structure based on seniority and rank rather than merit. Collectively, they show little patience for slowly moving up a hierarchy in order to have their voices heard and their opinion 
respected; they have grown up believing they are smart and they expect to be recognized for their contributions. Nevertheless, millennials' commitment to an organization has limits as they seek balance between employment and life outside of work. (Abrahamson, 2004).

Kriegel (2016) argues that societal and cultural changes, especially those taking place inside businesses, are mostly the result of "the seismic impact of technology in our lives," and she warns against using broad generational stereotypes to guide our actions as "we try to understand our colleagues who, for whatever reason, are different from us." Nevertheless, the migration of a labor force from one whose members can recall the first personal computer to a labor force whose members have lived an entirely digital life is bound to represent dynamic change even if many of the descriptions applied to the younger generation are over simplifications, as Kriegel would argue. (2016, p. 6). When applied to educating a new generation of news industry leaders, Marron suggested that journalism programs must do a better job of figuring out who the students are. For example, Marron notes that millennials are more than 40 percent non-white, which is the most diverse of any of the generational bands to come before them. She writes: "As journalism educators undertake curricular change to adapt to a fastpaced digital revolution, understanding 'the audience' in the teaching-learning relationship - our students - sometimes lacks priority (Marron, p. 123.).

Incorporating a LWB- model mindset into journalism education inherently makes learning about the student a priority as educators prepare students to interpret their own leadership styles. It would adopt a coaching structure, the dynamics of which encourage student introspection and collaboration. We believe teaching and mentoring possibilities in the LWB model are more aligned with generational sensibilities for addressing technological change, leveraging an entrepreneurial spirit, and fostering the resilience needed to withstand intense criticism.

\section{Conclusion: The LWB Model as a News Industry Solution}

The LWB model's flat table design addresses the desires of younger workforce members for meaningful engagement and it offers a dynamic tool for an industry where new approaches are an urgent necessity. The model appeals to the social motivations most relevant to a younger generation of journalists. Because it encourages non-hierarchical communication, the LWB model focuses on deepening a sense of purpose and expanding the capabilities of organizational members such that they can successfully navigate difficult and complex environments. The LWB leadership model assumes that millennials are full of potential and creates an environment that promotes their long-term well-being (Labarre, 2011).

Millennials tend to be socially aware of their work context. They were taught to be inclusive and accepting of diversity. They also have a low tolerance for injustice. They gravitate to organizations that understand the importance of respecting the local community (Heathfield, 2015; Jayson, 2006). These attributes align with earlier news industry research that found effective news leaders exhibited a characteristic described as "social aggressiveness" and "a willingness to stand up for what is right" (Fink, 1996; p. 85). However, Fink cautioned that "for ethical questions, there are no rulebook answers," and he prescribed introspection: "The burden for you as aspiring managers is to begin, now, working out where you stand on compelling issues 
of the day" (1996, p. 427). Missing from his advice, however, was a process for sorting through the issues in order to understand them in the terms of informational justice and interpersonal justice. Both are essential for creating the reciprocal communications necessary for producing tangible results.

A leadership model embraced by the news industry must include an ethical foundation that emphasizes journalistic integrity is not a side issue. Ethics are essential to the deliberate considerations in the decision-making process. Approaches to both community and marketplace are then framed by the consideration of fairness. A sense of ethical purpose driven by personal integrity allows LWB news media leaders to give priority to improving the prosperity of a beleaguered industry.

LWB news media leaders must understand they do not hold the only truth. They build trust by refraining from summarily criticizing and/or rejecting the voice of others. Journalists need the freedom to express themselves in unrehearsed and original fashion so that a variety of views influence the shared vision of the news organization and, hopefully, of the industry. A communication style that is underpinned by a fairness-focused moral compass is at the heart of this framework.

Foreman (2016) asserted that journalists are motivated to be ethical by moral and practical incentives. From a moral perspective, he found that journalists "want to see themselves as decent and honest." He added that "as much as they like getting a good story, journalists don't want to be known for having exploited someone in the process." On practical grounds, Foreman concluded that ethics in the news industry is simply good business. "In the long term, ethical journalism promotes the news organization's credibility and thus its acceptance by the public," he wrote. "What journalists have to sell is the news - and if the public does not believe their reporting, they have nothing to sell" (p. 5).

Embracing the concepts of the LWB leadership model enables news organizations to systemically emphasize journalism's social responsibility, which is to root out corruption and give a voice to the voiceless. In that setting, the LWB leadership model becomes a recipe for reform both in the practices of contemporary newsrooms and in the education of their next generation of leaders. 


\section{References}

Abrahamson, E. (2004). Change without pain. Cambridge, MA: Harvard Business School Press.

Bell, B. S., \& Kozlowski, S. W. J. (2002). A typology of virtual teams: implications for effective leadership. Group and Organization Management, 27(1), 14-49.

Breeden, J. (2013). Tipping sacred cows: Kick the bad work habits that masquerade as virtues. New York: Wiley.

Brocker, J., Konovsky, M., Cooper-Schneider, R., Folger, R., Martin, C., \& Bies, R. (1994). Interactive effects of procedural justice and outcome negativity on victims and survivors of job loss. Academy of Management Journal, 37 (2), 397-409.

Bunderson, J. S. (2001). Normal injustices and morality in complex organizations. Journal of Business Ethics, 33 (3), 181-190.

Coffey III, S. (2002). Best practices: The art of leadership in news organizations. Arlington, VA: Freedom Forum.

Colquitt, J.A. (2001). On the dimensionality of organizational justice: A construct validation of a measure. Journal of Applied Psychology, 86(3), 386-400.

Covey, S. (1990). The 7 habits of highly effective people. Powerful lessons in personal change. London: UK: Simon \& Shuster.

Dantley, M. E., \& Tillman, L. C. (2006). Social justice and moral transformative leadership. In C. Marshall and M. Oliva (Eds.), Leadership for social justice: Making revolutions in education (16-30). Boston: Pearson Education.

De Pree, M. (2003). Leadership is an art. New York: Dell.

De Pree, M. (1997). Leading without power: finding hope in serving community. Lavoisier S.A.S. (translated).

Fink, C. C. (1996). Strategic newspaper management. Boston, MA : Allyn and Bacon.

Folger, R., \& Bies, R. J. (1989). Managerial responsibilities and procedural justice. Employee Responsibilities \& Rights Journal, 2(2), 79-90.

Foreman, G. (2016). The ethical journalist: Making responsible decisions in the digital age $\left(2^{\text {nd }}\right.$ ed.). Malden, MA: Wiley Blackwell.

Förster, K \& Rohn, U. (2015). Media management education: Key themes, pedagogies, and challenges. Journalism \& Mass Communication Educator, 70 (4), 367-381. 
Fry, R. (2016, April 25). Millennials overtake Baby Boomers as America's largest generation. Pew Research Center. Retrieved from http://www.pewresearch.org/fact-tank/2016/04/25/ millennials-overtake-baby-boomers/.

Fry, R. (2015, May 11). Millennials surpass Gen Xers as the largest generation in U.S. labor force. Pew Research Center. Retrieved from http://www.pewresearch.org/facttank/2015/05/11/millennials-surpass-gen-xers-as-the-largest-generation-in-u-s-laborforce/.

Gaglio, C.M., \& Katz, J.A. (2001). The Psychological basis of opportunity identification: Entrepreneurial Alertness. Small Business Economics, 16, 95-111.

Graham, J. (1991). Servant-leadership in organizations: Inspirational and moral. The Leadership Quarterly, 2 (2), 105-119.

Greenberg, J. (1990). Organizational justice: Yesterday, today, and tomorrow. Journal of Management, 16 (2), 399-432.

Greenleaf, R. (1977). Servant leadership: A journey into the nature of legitimate power and greatness. Mahwah, NJ: Paulist Press.

Griffin, R. (2017). When Trump talks about 'fake news,' he probably means Russia coverage. Poynter Institute. Retrieved from http://www.poynter.org/2017/when-trump-talks-aboutfake-news-he-probably-means-russia-coverage/455505/.

Grynbaum, M.E. (2017, February 17). Trump Calls the News Media the 'Enemy of the American People.' Retrieved from https://www.nytimes.com/2017/02/17/business/trumpcalls-the-news-media-the-enemy-of-the-people.html?_r=0.

Hambley, L. A., O’Neill, T. A., \& Kline, T. J. (2007). Virtual team leadership: The effects of leadership style and communication medium on team interaction styles and outcomes. Organizational Behavior and Human Decision Processes, 103(1), 1-20.

Heathfield, S.M. (2015, July 14). Managing millennials: Eleven tips for managing millennials. About.com Money. Retrieved from http://humanresources.about.com/od/managementtips /a/millenials.htm.

Hesselbein, F. (2010). An audio recording as interviewed by Debbie Kennedy, August 10.

Jayson, S. (2006, June 29). The 'millennials' come of age. USA Today. Retrieved from http://www.usatoday.com/life/lifestyle/2006-06-28-generation-next_x.htm.

Joseph, J. (2012). Leadership as a way of being. Durham, NC: Duke University Press. 
Kernan, M.C., \& Hanges, P.J. (2002). Survivor reactions to reorganization: Antecedents and consequences of procedural, interpersonal, informational Justice. Journal of Applied Psychology, 87 (5), 916-928.

Kriegel, J. (2016). Unfairly labeled: How your workplace can benefit from ditching generational stereotypes. Hoboken, NJ: Wiley.

Labarre, P. (2011, December 30). Developing mindful leaders. Harvard Business Review. Retrieved from https://hbr.org/2011/12/developing-mindful-leaders.

Larson, C. L., \& Murtadha, K. (2002). Leadership for social justice. In J. Murphy (Ed.), The educational leadership challenge: Redefining leadership for the 21st century (pp. 134161). Chicago: University of Chicago Press.

Lichterman, J. (2016, June 7). There are now more Americans working for online-only outlets than newspapers. NiemanLab. Retrieved from http://www.niemanlab.org/2016/06/thereare-now-more-americans-working-for-online-only-outlets-than-newspapers/.

Mayer, D. M., Nishii, L. H., Schneider, B., \& Goldstein, H. (2007). The precursors and products of justice climates: Group leader antecedents and employee attitudinal consequences (CAHRS Working Paper \#07-09). Ithaca, NY: Cornell University, School of Industrial and Labor Relations, Center for Advanced Human Resource Studies.

Mann, G., Venturini, F. \& Malhotra, E. (2016). The future of broadcasting V: The search for fundamental growth. Accenture. Retrieved from https://www.accenture.com/t20160422T10 3424 w /us-en/_acnmedia/Accenture/nextgen/pulse-of-media/pdf/Accenture_Future _of_Broadcast_V_POV.pdf.

Marron, M.B. (2015). New generations require changes beyond the digital. Journalism \& Communication Educator, 70 (2), 123-124.

McCline, R., Bhat, S. \& Baj, P. (2000). Opportunity recognition: An exploratory investigation of a component of the entrepreneurial process in the context of the health care industry, Entrepreneurship: Theory and Practice, 25 (2), 81-94.

Nelson, J. L. \& Lewis, D. A. (2015). Training social justice journalists: A case study. Journalism \& Mass Communication Educator, 70 (4), 394-406.

Pavlik, J. V. (2013). A vision for transformative leadership: Rethinking journalism and mass communication education for the twenty-first century. Journalism \& Mass Communication Educator, 68 (3), 211-221.

Poon, R. (2006). A model for servant leadership; self-efficacy and mentorship. Servant Leadership Research Roundtable. Conference Proceeding, August, 2006. 
Porter, L.W., \& Siegel, J. (2006). Relationship of tall and flat organization structure to the satisfaction of foreign managers, Personnel Psychology, 18 (4), 379-392.

Rikleen, L.S. (2014) You raised us - now work with us: Millennials, career success, and building strong workplace teams. Chicago: American Bar Association.

Russell, R.F. (2001). The role of values in servant leadership. Leadership \& Organization Development Journal, 22 (2), 76 - 84.

Senge, P. M. (2006). The fifth discipline: The art \& practice of the learning organization. New York: Crown Publishing.

Timmons, J. (1989). The entrepreneurial mind. Andover: MA: Brick House.

Timmons, J. \& Spinelli, S. (2009). New Venture Creation, Entrepreneurship for the $21^{\text {st }}$ Century. Columbus, OH: McGraw-Hill. 